\title{
REVIEW: CURRENT TRENDS IN OAT PROTEIN RECOVERY AND UTILIZATION IN AQUEOUS FOOD SYSTEMS
}

\author{
*Darius Sargautis ${ }^{1}$, Tatjana Kince ${ }^{1}$, Vanda Sargautiene ${ }^{2}$ \\ ${ }^{1}$ Latvia University of Life Sciences and Technologies, Latvia \\ ${ }^{2}$ University of Latvia, Latvia \\ *Corresponding author's email: darius.sargautis@outlook.com
}

\begin{abstract}
Oat protein itself, as a substance, has extensively been studied providing information on its nutritional value, some functional properties and possible applicability in food systems. Chosen protein isolation methods and technological aspects define final composition of obtained oat protein product, its concentration, nutrition value and its functionality in food industry. Scientific data on oat protein recovery methods, typically relying on protein solubility or dry fractionation, provides an insufficient knowledge about the success in commercialization of oat protein recovery technologies and their derivatives in form of oat protein. The aim of the study was to analyse and summarize the research findings on oat protein extraction methods and functional properties of oat protein. Semi-systematic, monographic methods were used to analyse the oat protein isolation techniques, functional properties of oat protein in aqueous food systems, covering the latest information on oat protein extraction methods. Wet and dry isolation methods were demonstrated as main methods in oat protein extraction. Functional properties of oat protein, such as thermal stability, solubility, emulsification, water hydration capacity and foaming were reviewed and evaluated, identifying limitations and protein alterations which occur through the oat protein extraction process. The study provides recent trends in oat protein recovery technologies, along with an overview of current and potential oat protein utilization in food systems.
\end{abstract}

Key words: oat protein, functionality, recovery, isolation, trends.

\section{Introduction}

Protein is an essential element for existence of living beings. It is responsible for proper grow and maintenance of body's inherent nitrogenous compounds. Delivering the sufficient amount of protein for metabolic demand which is expected to be utilized at a high efficiency is one of the primary's task in food supply systems. Among the many available protein sources, plant protein is the most important. The plant origin protein consumed in food counts at least $60 \%$ (Kawakatsu \& Takaiwa, 2017; Krishnan \& Coe, 2001). The cereal protein as a class predominates, counting about $40 \%$ of protein consumed in the world (Kawakatsu \& Takaiwa, 2017). Typically, the protein of most cereals classified by Osborne fractionation method are alcohol-soluble prolamines (Walburg \& Larkins, 1983). High content of glutamic acid, glutamine and proline inherent to cultivars Triticaceae stimulate the induction of the Celiac disease (Wieser, 2001). Oats (Avena sativa) along with rice (Oryza sativa) are the exception. Main amount of protein in these seeds is stored mainly as globulin (Shewry, Napier, \& Tatham, 1995) which amino acid profile is typically more valuable when compared to glutelin rich crops such as wheat (Triticum aestivum) or corn (Zea mays). Amino acid composition of oat globulin demonstrate similarity to soy (Glycine max) glycinin. Exceptions were observed for tyrosyne and phenylalanine which were higher in oat globulin and aspartic acid, proline, lysine those were lower (Brinegar \& Peterson, 1982).

Despite being positively valued, the oat protein is not widely available, especially in concentrated form.
Moreover, protein isolation methods directly influence protein functional properties which subsequently impact protein applicability in food systems.

The aim of the study is to review the research findings on oat protein extraction methods and functional properties of oat protein.

\section{Materials and Methods}

Scientific databases Scopus and Web of Science were studied with the aim to cover available oat protein formation, extraction methods and oat protein functionality in aqueous food systems. Free sources available on the Internet, including but not limited to patents, companies web pages, fundamental documents, theses related to oat protein extraction methods and technologies, oat protein application and future trends were studied to analyze and summarize the information. Semi-systematic, monographic methods were used in the study.

\section{Results and Discussion}

Oat protein is typically recovered applying dry or wet fractionating methods discussed below. The wet fractioning method might consequently be divided into the three main groups: solvent extraction, precipitation and enzymatic extraction.

\section{Dry oat protein isolation method}

Kaukovirta-Norja, et al. (2008) patented a method for fractionating oat. Oat protein was separated as a by-product fraction in oat beta glucan purification. Supercritical carbon dioxide system was employed to extract lipids. In some examples the carbon dioxide was used in combination with ethanol. Defatted oat 
material passes milling, sieving and air separation steps. Fractionating allows to achieve protein content up to $78 \%$ in specific fractions. Unfortunately, the yield of protein concentrate remains unknown.

Lipids' removal could improve the fractioning process. Sibakov et al. (2011) reported the protein mass yield of 5\% for dry fractionating. Yet the protein concentration could be as high as $73 \%$ when oats initial material is defatted. Researchers used supercritical $\mathrm{CO}_{2}$ to remove oil from oats. The trials run at pilot scale although the amount $(2310 \mathrm{~kg})$ used for this trial demonstrated that the process might be scaled up.

Wet oat protein isolation methods

Wet fractioning method typically is divided into three main methods: solvent extraction, precipitation and enzymatic extraction, which were discussed below.

Yue et al. (2021) reported protein yields and structure extracted by choline chloride-dihydric alcohol deep eutectic solvent (DES) and its water binary mixtures. Protein was extracted subjecting oat flour to DES in the ration 1:9, which was then heated up to 80 ${ }^{\circ} \mathrm{C}$ for 60-120 minutes. Claimed method as being ecofriendly, due to its good biodegradability, low toxicity and being easy to apply in food, yielded in protein from 3.2 to $11.8 \%$ with the protein concentration of 38.9 to $55.8 \%$. Protein recovery ranged from 13.9 to $41.4 \%$. The optimal time of extraction was suggested to $90 \mathrm{~min}$ at the temperature of $80^{\circ} \mathrm{C}$.

The oat protein was isolated by $\mathrm{Ma}$ (1983) applying alkaline and salt extracts. Both extracts had higher than $90 \%$ concentration of protein. However, the yield of protein was much higher in alkaline extract than salt, counting $60 \%$ and $25 \%$, respectively. Both isolates had close amino acid composition, slightly observed higher lysine and total essential amino acid content in alkaline isolate. For alkaline isolation, the $\mathrm{pH}$ was adjusted to 9.5 using diluted $\mathrm{NaOH}(0.015$ $N)$ at ratio $1: 8$, then centrifuged and supernatant was neutralized, recentrifuged and frieze-dried. Salt based oat protein isolate was obtained mixing diluting initial oat material with $0.5 \mathrm{M} \mathrm{CaCl}$ at a ratio $1: 10$, then centrifuged and dialyzed against cold water, precipitated, centrifuged and freeze-dried. This research was close to earlier studies by Cluskey et al. (1976) who revealed a method to produce oat protein concentrate by wet extraction. Researches used $\mathrm{NaOH}$ to maintain the slurry at $\mathrm{pH} 9$ during extraction. Later Liu et al. (2009) isolated the oat protein by applying isoelectric precipitation to investigate oat protein composition and secondary structure. They applied alkaline extraction method close to what Ma (1983) reported. Oat flour was mixed with water, $\mathrm{pH}$ adjusted to 10.0 using $2 \mathrm{M} \mathrm{NaOH}$. Filtered by mesh, the slurry was centrifuged at $3000 \mathrm{~g}$. The supernatant had been centrifuged after $\mathrm{pH}$ was adjusted to 5.0 by $0.5 \mathrm{HCl}$ and kept for $15 \mathrm{~min}$ at room temperature. The resultant was washed 3 times, $\mathrm{pH}$ adjusted to 7.0 and friezedried. The oat protein concentration reached $87.0 \%$. The amino acid balance was found similar to the initial oat material. Researchers reported an apparent increase of isoleucine, methionine, phenylalanine and arginine whereas asparagine, serine, glycine and cysteine were at lower content when compared to oat flour. The lysine and methionine content have not reached recommended by WHO/FAO/UNU (2007) values. Sodium dodecyl sulphate-polyacrylamide gel electrophoresis (SDS-PAGE) showed dominant two bands of protein with molecular weights (MW) of abt. $36 \mathrm{kDa}$ and $22 \mathrm{kDa}$. These two agglomerates of peptides contributed to $80 \%$ of total protein. The secondary structure of oat protein isolate counted approximately $74 \%, 19 \%$ and $7 \%$ of $\beta$-sheet, $\alpha$-helix and $\beta$-turn, respectively. Also, the ability of oat protein concentrate to self-assemble in aqueous solutions when concentration is higher than $0.5 \mathrm{mg} \mathrm{mL}^{-1}$ was mentioned. That should increase the stability of protein in aqueous solutions by forming large aggregates (Liu et al., 2009). Unfortunately, the yield of oat protein isolate was not reported.

A method of oat protein isolation applying enzymatic treatment was demonstrated by Prosekov et al. (2018). Defatted oat brans were treated by amyloglucosidase. It was supposed that the breakdown of cell wall polysaccharide membrane might led to protein releasing into suspension which later was separated. Suspended solids were washed forming fraction rich in protein, which concentration counted up to $83.8 \%$ (Dumas method). Although yield was not reported, the functional properties of the obtained protein were enhanced comparing to alkali extraction methods and discussed below. Another yet research demonstrated combined, enzymatic and alkaline method of oat protein extraction from oat brans (Jodayree, Smith, \& Tsopmo, 2012). The oat protein was extracted applying different enzymes preparations, specifically with main enzymatic activities of xylanase, alpha amylase, amyloglucosidase, cellulase. Later slurries were treated with $2 M \mathrm{NaOH}$ to adjust $\mathrm{pH}$ to 9.5 and centrifuged. Supernatant was collected and precipitated. The highest protein concentration $82 \%$ (by modified Lowry method) was observed in the sample which had been treated with amyloglucosidase. Thereafter the obtained protein isolates were treated with endo-protease to enhance antioxidative properties.

Protein as a by-product

Oats are typically considered as a crop rich in healthy ingredients in particular non-starch polysaccharides extraction of those being a primarily technological process. Remaining protein rich fractions might be concentrated to high protein content 
products. Vasanthan and Timelli (2008) invented the method of beta glucan extraction with the by-products recovery including protein, starch, fiber. Some side streams side remaining from ethanol extracted oat beta glucan and additionally treated by proteases could later be concentrated. Inglett (Patent No. US005082673A, 1992) patented process of hydrolyzing grain and starch with alpha amylase and recovering the soluble fraction. Recovered fraction contained the desired fraction of beta glucan, while the undesired fraction, insoluble residue, contained protein. Protein concentration depended on $\mathrm{pH}$ level which varied from 6 to 11 . Concentration of protein in some examples reached up to $66 \%$. Yield of protein in both references was not emphasized. Later Liu (2014) showed a modified wet fractioning method separating oats into beta glucan, protein, starch and other carbohydrates. The protein was extracted precipitating alkaline supernatant which was produced by providing milled groats, mixing it with water, centrifuging and extracting the residue in alkaline medium so that to obtain the supernatant. That resulted in protein concentration up to $92.62 \%$. Beta glucan and starch were extracted in other streams with concentration of beta glucan and starch up to $44.84 \%$ and $81.69 \%$, respectively. It was reported that defatting did not improve protein yield, although the increase in protein concentration was observed. Sibakov et al. (2011) fractioned defatted oats by air to obtain oat beta glucan, which resulted in mass yield of $7.8 \%$ of initial mass with a concentration of beta glucan $33.9 \%$.

Functional properties of oat protein

The functional properties of oat protein such as thermal stability, solubility, emulsification, water hydration capacity and emulsification that are relevant to liquid food systems are being discussed below in the article.

Heat treatment is considered as a method which might modify protein functional properties. Marcone, Kakuda \& Yada (1998) investigated oat globulin denaturation temperature. To specify the effect of heating the researchers determined thermal stability which relied on stabilizing structural factors (amino acid composition, compact packing/protein-protein contacts, intramolecular linkages and interactions). The oat globulin thermal transition occurred at 112 ${ }^{\circ} \mathrm{C}$, the highest among all measured proteins.

Solubility of the protein is one of the most important factors when the protein functionality is discussed (Zayas, 1997). Kinsella (1976) described it as an obligatory determined method when studying a new or modified protein. Oat protein along with other cereal proteins typically has relatively low solubility. The solubility of oat protein highly depends on $\mathrm{pH}$ rate. Minimum solubility was observed at $\mathrm{pH}$ 5 and 6 for proteins extracted by alkaline and salt methods, respectively. Despite the similarity of oat globulins to the $11 \mathrm{~S}$ globulins of legumes, oat protein demonstrates lesser solubility in salt-based solutions (Brinegar \& Peterson, 1982). Loponen et al. (2007) investigated solubility of oat globulins isolated from oat brans. The protein behavior was monitored under lactic acid fermentation conditions controlling $\mathrm{pH}$ and salt concentration. At $\mathrm{pH}$ from 7 to 8 protein dissolved or demonstrated acceptable solubility in solutions with $1 M \mathrm{NaCl}$ and $0.5 M \mathrm{NaCl}$, respectively. At $\mathrm{pH} 5$ and lower at those salt concentrations protein became insoluble. In contrast, non-salt and low salt concentration $0.05 \mathrm{M} \mathrm{NaCl}$ did not prevent to soluble the protein at acidic conditions. Solubility started to rise sharply at pH 4 and lower. Loponen et al. (2007) speculated that acidic conditions which present during lactic acid fermentation could induce protein unfolding. That might cause the formation of globulin aggregates which consequently reduced protein solubility in saltbuffer. Contrasted explanation of protein solubility in low or non-salt solution was not presented. Prosekov et al. (2018) reported high solubility for oat protein extracted enzymatically by amyloglucosidase. Unexpectedly, the optimal solubility of oat protein was achieved at $\mathrm{pH} 5-6$. Nitrogen solubility index equaled approximately to $50 \%$. The achieved solubility was about 4 times higher than comparing to protein extracted by $\mathrm{NaOH}$. Another yet embodiment of increasing protein solubility was reported by Guan et al. (2007). Oat protein derived from oat brans was prepared by alkali extraction and then treated by trypsin. The solubility of trypsin treated oat protein at $\mathrm{pH} 5$ reached up to $68.2 \%$, while non-treated protein solubility was $7.3 \%$ only. The increase in solubility was observed when protein was treated in more alkali or acid medium. Guan et al. (2007) supposed the increased solubility might be related to structure demolishing, molecular size decreasing and exposing more charged and polar groups to surrounding water. Jiang et al. (2015) nearly doubled oat protein solubility after oat protein enzymatic deamidation. Oat protein fractions obtained through air separation were treated by food grade protein-glutaminase. Runyon et al. (2015) investigated oat protein solubility dependence on temperature treatment. Oats treated by steam at $102{ }^{\circ} \mathrm{C}$ for $50 \mathrm{~min}$ and then dried at $110-120{ }^{\circ} \mathrm{C}$ for $50 \mathrm{~min}$ reduced in availability of soluble protein up to $50 \%$. Albumins and prolamins were affected at higher extent that comparing to globulin fraction. Solubility test assumed oat protein extraction from oat flour in $200 \mathrm{~m} M$ sodium phosphate buffer at $\mathrm{pH} 9.5$ which contained protease inhibitor. Mirmoghtadaie, Kadivar \& Shahedi (2009) demonstrated the effect of succinylation and deamidation on functional oat protein isolate properties. Oat protein was isolated from oat flour which was diluted in $\mathrm{NaOH}$ solvent by precipitating, neutralizing and freeze drying. 
Deamidation and succinylation increased oat protein solubility index, from $22.9 \%$ to $24.2 \%$ and $86.8 \%$ respectively. Authors stated such a dramatic solubility increase of succinylated protein was caused by increased its net negative charge and increased protein-water interactions. Yue et al. reported (2021) decreasing in solubility of oat protein which was prior subjected to DES. It was speculated that higher amount of $\beta$-sheet and $\beta$-turn in oat protein extracted by the mentioned method 'may counteract the positive contribution of hydrophilic amino acidsresidues on oat protein solubility'. However, oat protein solubility increased when oat protein was extracted by 1,4-butanediol based DES/water binary mixture. On the other hand, the declination of solubility was reported when 2,3- butanediol based DES/water binary mixture was applied for extraction.

The emulsification of protein might be dependent on protein secondary structure and protein ability to self-assembly forming the protein adsorption layer at the water-air interface (Liu et al., 2009). The emulsification properties of oat protein isolate extracted in alkaline medium demonstrated close values to soy isolate, whereas the oats' isolate extracted in salt medium emulsification properties were less effective. Ma (1983) determined emulsification properties of oat isolate at different $\mathrm{pH}$. The weakest emulsification activity was observed between $\mathrm{pH} 4-6$. Bell shaped curves resembled the protein solubility curves where the minimum solubility of protein was determined at the identical pH. Surface hydrophobicity influences the functionality of protein greatly, particularly in emulsification (Nishinari, 2014; Chen et al., 2016). We could speculate relying on the similarity of oat globulins to soy globulins, that the large protein molecular mass and inherent hydrophobic interactions between nonpolar groups might oat protein turn into a proper emulsifier if modified adequately. Ma (1983) determined the surface and exposed hydrophobicities for oat protein isolate. The expressed values of surface hydrophobicity for alkaline isolate ranged from 240 to 269 , depending on oat variety. In comparison, soy protein isolate and wheat gluten showed 95 and 75, respectively. Enzymatically treated by protease, oat protein demonstrated improved emulsifying activity; meanwhile, the emulsifying stability has been reported as being poorer comparing to untreated or temperature treated oat protein. It was suggested the shorter and less globular protein layers formed less stable protein layers around the oil droplets (Guan et al., 2007).

Deamidation and succynilation increased emulsion activity of oat protein isolate (Mirmoghtadaie, Kadivar, \& Shahedi, 2009). Authors assumed that deamidation led to increase in solubility and surface hydrophobicity, yet increase in solubility and exposure of buried functional groups of protein were attributed to succynilaton. Emulsion activity was increased from $49.0 \mathrm{~m}^{2} \mathrm{~g}^{-1}$ to native oat protein to $98.3 \mathrm{~m}^{2} \mathrm{~g}^{-1}$ and 189 $\mathrm{m}^{2} \mathrm{~g}^{-1}$ after altering it by deamidation and succynilation, respectively. On the other hand, emulsion stability index for deamidated protein was slightly lower than native protein, yet succynilated protein decreased to $1692 \mathrm{~s}$ from $3756 \mathrm{~s}$ in terms of emulsion stability.

Water hydration capacity determined using of oat protein isolate was considerably lower than comparing to soy isolate, $0.8 \mathrm{~mL} \mathrm{~g}^{-1}$ to $2.5 \mathrm{~mL} \mathrm{~g}^{-1}$. It was close to wheat gluten capacity which was in the range of $1.0 \mathrm{~mL} \mathrm{~g}^{-1}$ (Yung Ma, 1983). Later functionality test was presented by Ma (1983) for oat concentrates. The hydration capacity for oat concentrates prepared by alkali extraction increased significantly comparing to oat isolates. The water hydration capacity was up to $2.70 \mathrm{~mL} \mathrm{~g}^{-1}$. Defatted by hexane oat protein concentrates showed lower hydration capacity. Interestingly, the dried supernatant rich in carbohydrates (59.6\%) also demonstrated significantly higher water holding capacity, $3.0 \mathrm{~mL} \mathrm{~g}^{-1}$. Based on this data we could speculate that the water holding capacity of the oats protein heavily depends on the level of carbohydrates which are present in the analyzed sample. Another yet research (Prosekov et $a l ., 2018$ ) found the water holding capacity for protein extracted by enzymatic method $3.73 \mathrm{~mL} \mathrm{~g}^{-1}$. Protein was extracted from oat brans. The values announced are higher than compared to alkali extraction method.

Good foamability of oat protein isolate which was equal or in some cases higher than wheat gluten or soy protein isolate (Yung Ma, 1983) was revealed. In addition, oat protein foaming ability increased when treated by protease. However, the foaming stability demonstrated the opposite relationship (Guan et al., 2007). Foaming properties were also investigated by Prosekov et al. (2018) who determined the foaming ability and foam stability for enzymatically extracted oat protein. Researchers noticed increase in foaming ability while the foam stability decreased. Slight increase in foaming capacity was also observed after deamidation (Mirmoghtadaie, Kadivar, \& Shahedi, 2009). Moreover, the facilitation in formatting of elastic layer due to the small molecular size of deamidated protein was observed. The decreased foaming stability was in line with other observations investigating protein size reduction as excessive increase in charge prevents formation of elastic film at the air-liquid point due to reduced protein-protein interactions.

Limitations

The methods related to wet extraction do not disclose the altering properties or chemical changes of protein products. The harsh alkali or acid treatment usually leads to chemical changes in protein. Main of those were comprehensively presented by Cartus (2017). Two general chemical changes are usually 
observed - the formation of cross-linked amino acids, like lysinoalanine, lanthionine or histidinoalanine and racemization (epimerization) of L-amino acids into D-isomers. For instance, the formation of lysinoalanine begins at $\mathrm{pH} 9$, reaches maximum at 12.5 (Friedman, Levin, \& Noma, 1984). Temperature might also affect the formation of lysinoalanine; wheat gluten is affected even at $\mathrm{pH}$, then temperature reaches 100 ${ }^{\circ} \mathrm{C}$ (4h) (Sternberg \& Kim, 1977). These chemical changes affecting proteins are highly undesired, as those significantly decrease product quality and nutritional value. Many of studies mentioned that wet protein purification performed treating protein at critical conditions which might induce the formation of mentioned undesired chemical changes to some extent.

\section{Commercial Oat protein}

Despite the positive functional properties and relatively high nutritional value the oat protein in its concentrated form is not widely available. Some attempts to commercialize concentrated protein were typically raised in Scandinavian countries. Oat protein produced by Lattmanen (PrOatein Oat Protein Lantmannen Oats, n.d.) seems to be the only currently commercialized protein concentrate in the market. The product contains more than $50 \%$ of protein and is rich in oil and maltodextrins, counting about 16-19\% and $20-24 \%$ respectively. Company employs patented technology by which the oat protein concentrate is extracted from oat brans. The process comprises wet milling process during which oat material is mixed with aqueous liquid and treated with alpha amylase. The suspension is then decanted to remove insoluble fiber. Along with protein other oat derivatives, like oat beta glucan or oat dextrin might be obtained during the process. Company states the product is suitable for various applications including bakery, beverages, meat substitutes, etc. The oat product properties highly differ from traditional plant-based proteins such as soy or pea (Pisum sativum) in terms of oil content, structure and functional properties.

There were some attempts to establish production units in the USA, like Oat Tech, Inc. Company along with protein products similar to Latmannen product, concentrated some streams of oat dextrins. Company's product Oat Protein 55 produced by patented technology (Whalen, 2016) concentration was about $55 \%$. These attempts were not sustainable and the information available is very limited to discuss the issues which terminated Oatech's activity.

Some recent research in dry fractionating allows also to achieve high purity of protein wherein the concentration of protein could reach up to $73 \%$. Fazer company recently announced that it had obtained a license to VTT Research Centre of Finland (Fazer, 2015). Dry fractionating allows to retain protein in form providing its natural state although protein is yet not commercially available though not studied in the article. The protein fractions obtained through typical or slightly modified dry fractionation methods are not included in the study due to their low protein concentration and limited applicability in aqueous food systems.

\section{Conclusions}

Oat protein is a valuable source of protein. Amino acid composition of oat storage protein globulin is close to soy's glycinin with little imbalance.

Published oat protein extraction methods highly rely on wet extraction technique, in particular using precipitation method, which in some cases enables achieving of highly purified protein up to $90 \%$ of purity. However, such a method rises concerns about extracted protein further applicability in food as limitation such as formation of cross-linked amino acids might decrease protein value. Enzymatic protein extraction might be a future trend in oat protein extraction technique.

Relatively large oat protein molecular mass and inherent hydrophobic interaction between nonpolar groups might be positive preconditions for oat protein acting as a proper emulsifier. Water hydration capacity of oat protein is lower than compared to soy protein. Oat protein foaming ability is in range or in some cases higher than comparing to soy or wheat protein isolates. Protein modification in particular size reduction increases foamability properties while the foam stability decreases after such a modification.

Few technologies are currently commercially established. However, the increased demand on plantbased protein might stimulate development of oat protein isolation and modification technologies.

\section{References}

Brinegar, A.C., \& Peterson, D.M. (1982). Separation and characterization of oat globulin polypeptides. Archives of Biochemistry and Biophysics, 219(1), 71-79. DOI: 10.1016/0003-9861(82)90135-7.

Cartus, A. (2017). D-Amino Acids and Cross-Linked Amino Acids in Food. In D. Schrenk \& A. Cartus (Eds.), Chemical Contaminants and Residues in Food (Second Edition) (pp. 251-278). Woodhead Publishing. DOI: 10.1016/B978-0-08-100674-0.00012-6.

Chen, L., Chen, J., Yu, L., \& Wu, K. (2016). Improved emulsifying capabilities of hydrolysates of soy protein isolate pretreated with high pressure microfluidization. LWT - Food Science and Technology, 69, 1-8. DOI: 10.1016/j.lwt.2016.01.030. 
Cluskey, J.E., Wu, Y.V., Inglett, G.E., \& Wall, J.S. (1976). Oat protein concentrates for beverage fortification. Journal of Food Science, 41(4), 799-804. DOI: 10.1111/j.1365-2621.1976.tb00726_41_4.x.

Fazer. (2015, October 16). Fazer answers to the growing oat boom with a new technology. Retrieved January 30 , 2021, from: https:/www.bioeconomy.fi/fazer-answers-to-the-growing-oat-boom-with-a-new-technology/.

Friedman, M., Levin, C.E., \& Noma, A.T. (1984). Factors Governing Lysinoalanine Formation in Soy Proteins. Journal of Food Science, 49(5), 1282-1288. DOI: 10.1111/j.1365-2621.1984.tb14970.x.

Guan, X., Yao, H., Chen, Z., Shan, L., \& Zhang, M. (2007). Some functional properties of oat bran protein concentrate modified by trypsin. Food Chemistry, 101(1), 163-170. DOI: 10.1016/j.foodchem.2006.01.011.

Inglett, G.E. (1992). Patent No. US005082673A. Retrieved December 19, 2020, from https://patentimages. storage.googleapis.com/3a/53/b7/a4e4bcb5f0dc53/US5082673.pdf.

Jiang, Z., Sontag-Strohm, T., Salovaara, H., Sibakov, J., Kanerva, P., \& Loponen, J. (2015). Oat protein solubility and emulsion properties improved by enzymatic deamidation. Journal of Cereal Science, 64, 126-132. DOI: $10.1016 /$ j.jcs.2015.04.010.

Jodayree, S., Smith, J.C., \& Tsopmo, A. (2012). Use of carbohydrase to enhance protein extraction efficiency and antioxidative properties of oat bran protein hydrolysates. Food Research International, 46(1), 69-75. DOI: 10.1016/j.foodres.2011.12.004.

Kaukovirta-Norja, A., Myllymäki, O., Aro, H., Hietaniemi, V., \& Pihlava, J.-M. (2008). World Intellectual Property Organization Patent No. WO2008096044A1. Retrieved December 2, 2020, from https://patents. google.com/patent/WO2008096044A1/en.

Kawakatsu, T., \& Takaiwa, F. (2017). Proteins. In B. Thomas, B.G. Murray, \& D.J. Murphy (Eds.), Encyclopedia of Applied Plant Sciences (Second Edition) (pp. 100-105). Oxford: Academic Press. DOI: 10.1016/B9780-12-394807-6.00161-1.

Kinsella, J.E. (1976). Functional properties of proteins in foods: A survey. C R C Critical Reviews in Food Science and Nutrition, 7(3), 219-280. DOI: 10.1080/10408397609527208.

Krishnan, H.B., \& Coe, E.H. (2001). Seed Storage Proteins. In S. Brenner \& J. H. Miller (Eds.), Encyclopedia of Genetics (pp. 1782-1787). New York: Academic Press. DOI: 10.1006/rwgn.2001.1714.

Liu, G., Li, J., Shi, K., Wang, S., Chen, J., Liu, Y., \& Huang, Q. (2009). Composition, Secondary Structure, and Self-Assembly of Oat Protein Isolate. Journal of Agricultural and Food Chemistry, 57(11), 4552-4558. DOI: $10.1021 /$ jf900135e.

Liu, K. (2014). Fractionation of oats into products enriched with protein, beta-glucan, starch, or other carbohydrates. Journal of Cereal Science, 60(2), 317-322. DOI: 10.1016/j.jcs.2014.06.002.

Loponen, J., Laine, P., Sontag-Strohm, T., \& Salovaara, H. (2007). Behaviour of oat globulins in lactic acid fermentation of oat bran. European Food Research and Technology, 225(1), 105-110. DOI: 10.1007/ s00217-006-0387-9.

Ma, C.Y. (1983). Chemical Characterization and Functionality Assessment of Protein Concentrates from Oats. Cereal Chemistry, 60(1), 36-42.

Marcone, M.F., Kakuda, Y., \& Yada, R.Y. (1998). Salt-soluble seed globulins of dicotyledonous and monocotyledonous plants II. Structural characterization. Food Chemistry, 63(2), 265-274. DOI: 10.1016/ S0308-8146(97)00159-3.

Mirmoghtadaie, L., Kadivar, M., \& Shahedi, M. (2009). Effects of succinylation and deamidation on functional properties of oat protein isolate. Food Chemistry, 114(1), 127-131. DOI: 10.1016/j.foodchem.2008.09.025.

Nishinari, K. (2014). Soy proteins: A review on composition, aggregation and emulsification. Food Hydrocolloids, 18.

PrOatein oat protein. Lantmännen Oats. (n.d.). Retrieved January 30, 2021, from https://www.lantmannenoats. com/proatein/.

Prosekov, A., Babich, O., Kriger, O., Ivanova, S., Pavsky, V., Sukhikh, S., ... Kashirskih, E. (2018). Functional properties of the enzyme-modified protein from oat bran. Food Bioscience, 24, 46-49. DOI: 10.1016/j. fbio.2018.05.003.

Runyon, J.R., Sunilkumar, B.A., Nilsson, L., Rascon, A., \& Bergenståhl, B. (2015). The effect of heat treatment on the soluble protein content of oats. Journal of Cereal Science, 65, 119-124. DOI: 10.1016/j. jcs.2015.06.008.

Shewry, P.R., Napier, J.A., \& Tatham, A.S. (1995). Seed storage proteins: Structures and biosynthesis. The Plant Cell, 7(7), 945-956. DOI: 10.1105/tpc.7.7.945.

Sibakov, J., Myllymäki, O., Holopainen, U., Kaukovirta-Norja, A., Hietaniemi, V., Pihlava, J.M., Lehtinen, P. (2011). Lipid removal enhances separation of oat grain cell wall material from starch and protein. Journal of Cereal Science, 54(1), 104-109. DOI: 10.1016/j.jcs.2011.04.003. 
Sternberg, M., \& Kim, C.Y. (1977). Lysinoalanine Formation in Protein Food Ingredients. In M. Friedman (Ed.), Protein Crosslinking: Nutritional and Medical Consequences (pp. 73-84). Boston, MA: Springer US. DOI: 10.1007/978-1-4757-9113-6_5.

Vasanthan, T., \& Temelli, F. (2008). Grain fractionation technologies for cereal beta-glucan concentration. Food Research International, 41(9), 876-881. DOI: 10.1016/j.foodres.2008.07.022.

Walburg, G., \& Larkins, B.A. (1983). Oat Seed Globulin. Plant Physiology, 72(1), 161-165.

Whalen, P. (2016). Patent No. 9241505. Retrieved January 30, 2021, from http://patft.uspto.gov/netacgi/ nph-Parser?Sect $1=$ PTO $1 \&$ Sect $2=$ HITOFF $\& d=$ PALL $\& p=1 \& u=\% 2 F$ netahtml $\% 2 F P T O \% 2 F s r c h n u m$. $\mathrm{htm} \& \mathrm{r}=1 \& \mathrm{f}=\mathrm{G} \& \mathrm{l}=50 \& \mathrm{~s} 1=9241505 . \mathrm{PN} . \& O S=\mathrm{PN} / 9241505 \& \mathrm{RS}=\mathrm{PN} / 9241505$.

Wieser, H. (2001). Comparative investigations of gluten proteins from different wheat species. III. N-terminal amino acid sequences of $\alpha$-gliadins potentially toxic for coeliac patients. European Food Research and Technology, 213(3), 183-186. DOI: 10.1007/s002170100365.

World Health Organization/Food and Agriculture Organization/United Nations University (2007). Protein and Amino Acid Requirements in Human Nutrition Report of a Joint WHO/FAO/UNU Expert Consultation. WHO Technical Report Series no. 935. Geneva: WHO.

Yue, J., Zhu, Z., Yi, J., Lan, Y., Chen, B., \& Rao, J. (2021). Structure and functionality of oat protein extracted by choline chloride-dihydric alcohol deep eutectic solvent and its water binary mixtures. Food Hydrocolloids, 112, 106330. DOI: 10.1016/j.foodhyd.2020.106330.

Yung Ma, C. (1983). Preparation, Composition and Functional Properties of Oat Protein Isolates. Canadian Institute of Food Science and Technology Journal, 16(3), 201-205. DOI: 10.1016/S0315-5463(83)72208-X.

Zayas, J.F. (1997). Solubility of Proteins. In J.F. Zayas (Ed.), Functionality of Proteins in Food (pp. 6-75). Berlin, Heidelberg: Springer Berlin Heidelberg. DOI: 10.1007/978-3-642-59116-7_2. 